

\title{
The Impact of Covid-19 on the Malaysian Education System
}

\author{
S. Aisyah Sufian, N. Adilah Nordin, S. Shafia Nazar Tauji \& M. Khalid M. Nasir
}

To Link this Article: http://dx.doi.org/10.6007/IJARPED/v9-i2/7659

DOI:10.6007/IJARPED/v9-i2/7659

Received: 12 May 2020, Revised: 13 June 2020, Accepted: 29 June 2020

Published Online: 27 July 2020

In-Text Citation: (Sufian, Nordin, Tauji, \& Nasir, 2020)

To Cite this Article: Sufian, S. A., Nordin, N. A., Tauji, S. S. N. \& Nasir, M. K. M. (2020). The Impact of Covid-19 on the Malaysian Education System. International Journal of Academic Research in Progressive Education \& Development. 9(2), 764-774.

Copyright: (C) 2020 The Author(s)

Published by Human Resource Management Academic Research Society (www.hrmars.com)

This article is published under the Creative Commons Attribution (CC BY 4.0) license. Anyone may reproduce, distribute, translate and create derivative works of this article (for both commercial and non-commercial purposes), subject to full attribution to the original publication and authors. The full terms of this license may be seen

at: http://creativecommons.org/licences/by/4.0/legalcode

\section{Vol. 9(2) 2020, Pg. 764 - 774}

Full Terms \& Conditions of access and use can be found at http://hrmars.com/index.php/pages/detail/publication-ethics 


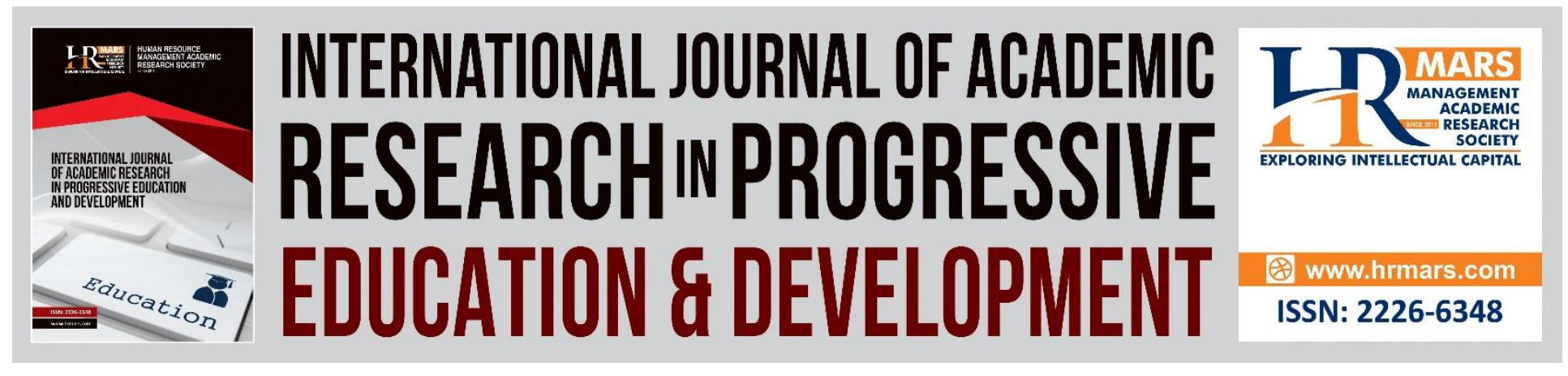

\title{
The Impact of Covid-19 on the Malaysian Education System
}

\author{
S. Aisyah Sufian, N. Adilah Nordin, S. Shafia Nazar Tauji \& M. \\ Khalid M. Nasir \\ Faculty of Education, Universiti Kebangsaan Malaysia (UKM) \\ Email: aisy.sufyan25@gmail.com,shafia_93@yahoo.com, are.deela94@gmail.com \\ mdkhalid@ukm.edu.my
}

\begin{abstract}
The recent outbreak of Corona Virus Disease 2019 (Covid-19) has affected society on a global scale, particularly in the areas of social sciences and behavioral aspects. Despite the alarming rate at which the virus is spreading, potential vaccines and treatments remain under clinical trial. Therefore, the most effective strategy to manage this situation would be through social distancing. In the context of the Malaysian education system, the multiple issues, and challenges, pending solutions due to the pandemic, were focused throughout this discussion on the effect of Covid-19 concerning virtual education. The findings on teaching and learning from home, utilizing technological advancement, group work, preparedness in education, alternatives by the government, internet access, and the student assessment process were highlighted in this concept paper on the impact of Covid-19 in Malaysia.
\end{abstract}

Keywords: Covid-19, Malaysian Education, Teaching, Learning

\section{Introduction}

With the recent emergence of Covid-19, the medical world has strived to understand the nature of the disease, specifically the symptoms involved, means of transmission, and contagious conditions upon infection. Although no vaccines or specific treatments were discovered, clinical trials are in progress, with the hope of making life-saving discoveries for the world population. As highlighted by the World Health Organization [WHO] (2020b), the early symptoms are dry cough, fever, and tiredness. As such, a person suffering from shortness of breath, inability to move or speak, and chest pain is a cause for alarm.

The world population has witnessed the rapid spread of the Covid-19 pandemic, with possible origins from a wet market in China selling frogs, birds, snakes, rats, and other dead and live exotic animals as food. These animals were suspected of carrying the virus currently threatening human health in unprecedented ways (Lan et al., 2019). Initially, WHO (2020a) reported a case of pneumonia in Wuhan City, China, on December 31, 2019, with 44 similar cases reported within only four days. On January 7,2020 , the Chinese authorities identified a new type 
of coronavirus related to previous pneumonia cases. Since then, the virus has swiftly spread and reached 282 cases of infection within the same month, thus forcing all the activities, specifically educational activities, to be restricted.

Similarly, the cities of Lodi and Bergamo in Italy were impacted by the virus at approximately the same time, as observed by Rotondi et al. (2020) with regards to social sciences and behavioral aspects (Bavel et al., 2020). As specific vaccines are yet to be created for treatment, the most convincing strategy to manage the Covid-19 pandemic was through social distancing. Nevertheless, this concept proved to be challenging due to human nature, which essentially needed human interaction.

Locally, the first Covid-19 case in Malaysia was recorded on January 25, 2020, involving three Chinese citizens from Wuhan (Mat et al., 2020) and has continued spreading rapidly every week (Rampal \& Liew, 2020), subsequently cresting the second wave with a total of 8266 cases (Abdullah, 2020b). The situation worsened when the Covid-19 cases went beyond imported cases to include local community members. Additionally, several cases demonstrated the ability of Covid-19 to infect individuals with no direct contact to the Wuhan market, where the virus originated from (Lan et al., 2019; Malaysian Ministry of Health, 2020), hence causing the restriction of all physical activities, including education.

From a few isolated cases that were epidemic, the rising number of infections led to a full-fledged pandemic haunting every individual. Epidemics are recognizable in situations where the spread of a disease surpassed the normal rate among a community within a certain period. Consequently, the epidemics evolved into pandemics when the number of cases spiked to a worldwide population (Suhaimi, 2020). Consequently, the pandemic caused concern by the fact that the virus was not contained within China but is currently spreading on a global scale. In this regard, Bavel et al. (2020) believed that the term 'physical distancing' was more accommodating to the current circumstance, as opposed to 'social distancing' in ensuring potential social bonding vital to human nature. Therefore, online interaction has gained focus as a means of boosting social movements virtually, in accordance with Bergman et al. (2020), who emphasized the need for physical distancing instead of a social one.

Although the Malaysian Ministry of Education [MMOE] (2020) initially published preventive measures to raise public awareness on Covid-19, the significant rise in positive cases led to the distribution of standard operating procedures as a guideline to ensure the health quality of school communities. For example, Abdullah (2020a) reported that up to May 16, 2020, 317 cases were reported, with 35\% involving children aged under four years and $7 \%$ involving babies aged under one year. Although the majority of death cases involved adults aged 40 years and above, there was an exception of a 23-year-old girl's demise due to Covid-19 (Abdullah, 2020c). Thus, this concept paper aimed to discuss and provide a holistic view of teaching and learning from home, the utilization of technological advancement, group work, preparedness in education, alternatives from the government, internet facilities, and student assessment methods due to the impact of Covid-19, specifically in the context of the Malaysian education system. 
DEVELOPMENT

Vol. 9, No. 2, 2020, E-ISSN: 2226-6348 @ 2020 HRMARS

\section{Teaching and Learning from Home}

Regarding the shift in teaching and learning from a school-oriented process to a virtual platform through online learning from home (MMOE, 2020a), Hamzah in Tahir \& Noorzali (2020) reported that most of the teachers were initiated into the concept of online learning through the implementation of Sekolah Bestari (Smart Schools). Several issues were discussed at the time, such as limited applications and the lack of technological infrastructures and internet access. Furthermore, Kamarudin et al. (2020) perceived open communication to be an under-utilized dimension by teachers, as information technology (IT) was not fully applied due to technical difficulties.

Hence, UNESCO (2020) suggested that teachers be given immediate training to enable familiarization with online learning techniques involving content, pedagogical methods, basic technological devices, free internet data, education materials, and peer guidance in meeting students' needs. Besides, virtual teaching and learning from home was a complex task requiring strong community support from teachers, parents, guardians, school administrators, and student motivation to track the continuance of learning and the students' progress in reaching optimum results as in physical classrooms (Khalid, \& Quick, 2016), particularly in the wake of this pandemic (Cahyani, 2020).

\section{Utilization of Technological Advancement}

Leow et al. (2020) reported that online discussions impacted students differently. For example, the indirect exchange of information and experiences could induce a sense of belonging and communal engagement (Nasir et al., 2018a; Nasir et al., 2018b), whereas an indirect meeting absolved students' fear in contributing information. Nevertheless, some students could not realize these values in situations where the discussion proved too overwhelming, emotional, or lacked professionalism.

On another note, online methods were perceived to limit the students' willingness to pose questions. The synchronized nature of online discussions was deemed inappropriate in meeting every individual's needs in a group. A similar situation was discussed by Simpson (2018), stating that students who coped well with the flow of discussion would inadvertently pose a threat to others who may feel excluded and lose self-confidence (Nasir et al., 2018a; Nasir et al., 2018b). Therefore, teachers were encouraged to explain the learning schedule prior to class hours and provide the necessary materials to prepare in advance, as students mostly relied on self-study to overcome the challenges in online classes (Rovai \& Downey, 2010), especially during the pandemic (Wisneski et al., 2017).

\section{Educational Application and Attitude}

With the impact of the Covid-19 pandemic at the primary, secondary, and tertiary levels of the education sector, the advent of various current educational technologies did not require the physical occurrence in teaching and learning, particularly in current times. As such, the United Nations' scientific and cultural organizations recommended the use of diverse technologies to enable the continuity of learning despite the constraints posed by the pandemic nationwide. Teachers could use online learning platforms to teach, interact, and provide virtual training sessions (Ali \& Nasir, 2019; Min \& Nasir, 2020), as many students currently have access to 
technological equipment at home, hence resulting in the implementation of virtual learning in Malaysia (Jidin, 2020).

The type of online platform used also raised concerns among teachers and students, such as information delivery platforms, the sharing of materials, training provided to students, discussions and presentations, editing audio and video files, and slideshows used in the teachinglearning process during the Covic-19 pandemic. Besides, the implementation of e-learning introduced electronic media and information and communication technology in education, which included all the forms of educational technologies in teaching and learning. E-learning also enhanced students' understanding and provided development in IT skills, specifically in terms of immediate access to information (Ali \& Nasir, 2019). Leow et al. (2020) reported that students were required to participate in online group assignments based on easy access to materials and information. In this regard, students may face difficulties in implementing online learning due to movement control orders (MCO) and the current critical situation.

\section{Group Work}

During the MCO in Malaysia from March 13 to curb the spread of the Covid-19 outbreak, all the students were ordered to attend virtual classes from home. Nonetheless, several challenges were found in e-learning from home, as some subject matters required elaboration, especially in the form of complex tasks needing careful explanations and discussions by other team members. As the Covid-19 threat required the maintaining of physical distancing to reduce infection rates, the MCO period allowed group members to explore the utilization of potential materials in fulfilling the assigned tasks and identifying the challenges involved in a novel experience, such as virtual groups. Hence, individuals' mental preparation, ability, and resources were the determinant factors in executing assigned tasks (MMOE, 2020a; 2020b).

Besides, students faced problems regarding time constraints, with insufficient time to comprehend the assigned tasks due to limited internet access, thus presenting a barrier in accessing information and task completion within the allotted time. Thus, effective learning methods could be highlighted by creating an effective learning schedule to complete tasks (MMOE, 2020b).

\section{Preparedness in Education}

The success or failure of homework completion depended on students' commitment, specifically during the MCO period (MMOE, 2020a; 2020b). Hence, students needed to show commitment to completing homework and provide feedback to classmates. During this period, students needed to be highly accountable for the entrusted work as a measure of integrity and ethics, subsequently inculcating self-discipline while at home without procrastination and molding strong, disciplined, and trustworthy individuals. Furthermore, students' ability to accommodate educational activities to the home environment is crucial, including the type of equipment utilized at home. For example, using laptops for typing, communicating, submitting important documents, accessing the internet, and having a dedicated study space significantly influenced students' homework performance.

Additionally, the Internet is a critical source of access during this period, as the need for high-speed data access impacted educational performance at home. For example, a slow 
network would affect the assigned work. In the MCO context, the key factor enabling task performance at home was digital communication and IT skills. Other factors include appropriate workspaces with desks, ergonomic chairs, and adequate lighting. Background images and voice clarity also needed consideration when participating in video presentations, as students participated in group work. (MMOE, 2020a; 2020b).

\section{Alternatives Given by the Government}

Based on a statement by the National Security Council (2020), Malaysians had to work and study from home during the Covid-19 pandemic, emphasizing the importance of having affordable and reliable internet access. For example, in multinational companies such as Microsoft, many changes were implemented in the Microsoft team applications, with the drastic increase of users from 12 million to 44 million a day worldwide (National Security Council, 2020). Thus, Ahmad (2020) recommended all the Malaysian higher education institutions to continue teaching and learning virtually. As quoted by the Malaysian Prime Minister from the National Security Council (2020), Malaysians should be given 1 Gigabyte of free data daily during the MCO period to support students' and teachers' virtual education (Abu, 2020).

\section{Internet Requirements}

With a gradual shift from conventional classrooms to a full-fledged virtual learning environment in local educational institutions, teachers and students resorted to online or distance learning in line with the social distancing enforcement on campuses. In this unprecedented situation, the availability of resources, such as advanced IT platforms and fast internet connections, were deemed essential, apart from basic computer facilities, such as laptops or personal computers. However, financial resources could be a vital component in handling and recovering from acute crises (Carvalho et al., 2016), as the abrupt closure of campuses imposed serious and unplanned financial burdens on students needing to leave on short notice. Therefore, the availability of emergency relief funds in the form of soft loans or private donations would aid students with daily expenses to continue studying.

Moreover, The Malaysia Internet Exchange (MyIX) association, under the Malaysian Communications and Multimedia Commission [MCMC] (2020), recorded a peak of 532 gigabytes per second (Gbps) in intermetal traffic peak during the MCO period from on March 18, as opposed to the previous record in 2019 at $500 \mathrm{Gbps}$. As such, MCMC observed that the internet traffic flow increased nationwide by 23.5 percent compared to the first week of MCO, and 8.6 percent in the second week, in line with Rizzato, Fenwick, and Fogg (2020). The average 4G download speed in Malaysia witnessed a drop, from 13.4 Megabits per second (Mbps) in early February to $8.8 \mathrm{Mbps}$ in the last week between March 23 and March 29, indicating that the increase in data usage caused internet traffic congestion and the subsequent decline in download speed.

According to Abdullah (2020d), internet access was generally divided into three parts: homes, offices, and roads. For example, three Malaysian telecommunication companies carefully monitored residential areas to ensure smooth internet access and network coverage improvement. Additionally, the Minister of Communications and Multimedia (2020) affirmed 
that telecommunication companies continuously strived to improve network coverage across particular residential areas with slow internet access.

\section{Student Assessment Process}

Regarding MMOE (2020), the postponement of national public examinations, such as the Sijil Pelajaran Malaysia (SPM), was inevitable in safeguarding students' and teachers' health and safety. Additionally, following MMOE's statement as quoted from Ahmad (2020), the Ujian Pencapaian Sekolah Rendah (UPSR) and Sistem Pentaksiran Tingkatan Tiga (PT3) for all the candidates for the year 2020 were canceled. Accordingly, Jidin (2020), as quoted from a private Malaysian satellite television provider, stated that the decision applied to all the government schools and aid schools, private schools, and other educational institutions registered under the Education Ministry. Furthermore, the Education Ministry made the right decision in revising the examination dates for the Sijil Tinggi Pelajaran Malaysia (STPM) and Sijil Tinggi Agama Malaysia (STAM) candidates to reduce teachers' workload and pressure in completing the current syllabi.

Following the Covid-19 pandemic, social support systems may provide valuable relief to individuals severely affected by the crisis. For example, individuals from the affected groups may require psychological help or counseling to prevent mental or emotional crises leading to severe stress and depression. Hence, the affected local communities must be resilient and develop appropriate solutions to overcome potential risks through an open, trustful, and learningoriented organizational culture (Sawalha, 2015).

Regarding Natasya Abdullah (2020), an assessment is an important learning aspect to be regularly conducted through remote online activities, such as assignments, projects, quizzes, and tests. Nevertheless, some parents, teachers, and students raised concerns about the fairness of online assessments. Also, the level of privacy and confidentiality in virtual education should be regarded to enable effective assessments. Although online assessment methods may seem new following the announcement by the Kementerian Pengajian Tinggi (KPT), practical assessments could pose difficulties when assessed virtually (MMOE, 2020a; 2020b).

\section{Conclusion}

The impact of Covid-19 on the Malaysian educational sector requires serious consideration in addressing the issue. As observed, over 1.5 billion students from over 156 countries could not continue physical schooling due to the worldwide Covid-19 pandemic (UNESCO, 2020). Furthermore, physical and social restrictions in preventing the Covid-19 spread was predicted to be a long healing process with no immediate solution in sight.

Therefore, the teachers' efforts in providing online learning platforms for students was essential (Ali \& Nasir, 2019). Additionally, other stakeholders, such as universities, schools, and the government, needed to play active roles in support, commitment, and financial aids. For example, some form of financial assistance was required to enable students to spend on IT gadgets. Nonetheless, not every individual could afford to purchase laptops or tablets, particularly concerning families with financial and geographical constraints.

Thus, the hurdles regarding virtual education from home, the utilization of technological equipment, group-based projects, internet capacity, and assessment methods were acknowledged through the impact of Covid-19, specifically in the Malaysian education system. 
The bottom line in this paper concerned the sense of awareness and togetherness of the local community in continuing the educational process despite the current odds. As such, courier services are recommended to send or receive educational materials, similar to traditional distance learning methods for individuals lacking internet access in rural areas, so that no students are neglected.

\section{Acknowledgement}

This paper and the research would not have been possible without the exceptional support from my dedicated lecturer, M. Khalid M. Nasir. His enthusiasm, knowledge and exacting attention to details have been an inspiration on keeping my work on track until the publication of this paper. The authors would also like to express special gratitude to the Faculty of Education, Universiti Kebangsaan Malaysia (UKM) and the team members under the project code GG2019021 and DCP-2017-020/3.

\section{About the Authors}

S. Aisyah Sufian, N. Adilah Nordin, \& S. Shafia Nazar Tauji are undergraduate's students at the Faculty of Education, National University of Malaysia, 43600 UKM, Bangi Selangor, Malaysia.

M. Khalid M. Nasir is a corresponding author, media coordinator, and a senior lecturer at the Centre Department of Innovation in Teaching \& Learning, Faculty of Education, National University of Malaysia, 43600 UKM, Bangi Selangor, Malaysia. His research interest is in Computer Education, Educational Technology, Instructional Technology, Community of Inquiry (Col) in Online learning.

\section{References}

Abu, M. A. (2020). Yayasan YTL bekerjasama dengan ukm beri kad sim percuma untuk tujuan pembelajaran. Retrieved 15 May 2020, from http://www.ukm.my/new/.Latest_news/yayasan-ytl-bekerjasama-dengan-ukm-berikad-sim-percuma-untuk-tujuan-pembelajaran

Abdullah, N. H. (2020a). Kenyataan akhbar KPK 16 Mei 2020 - Situasi semasa jangkitan penyakit Coronavirus 2019 (COVID-19) di Malaysia, From the Desk of the Director-General of Health Malaysia. $\quad$ https://kpkesihatan.com/2020/05/16/kenyataan-akhbar-kpk-16-mei-2020situasi-semasa-jangkitan-penyakit-coronavirus-2019-covid-19-di-malaysia/

Abdullah, N. H. (2020b). Kenyataan akhbar KPK 5 Jun 2020 - Situasi semasa jangkitan penyakit Coronavirus 2019 (COVID-19) di Malaysia, From the Desk of the Director-General of Health Malaysia. https://kpkesihatan.com/2020/06/05/kenyataan-akhbar-kpk-5-jun-2020situasi-semasa-jangkitan-penyakit-coronavirus-2019-covid-19-di-malaysia/

Abdullah, N. H. (2020c). Kenyataan akhbar KPK 9 April 2020 - Situasi semasa jangkitan penyakit Coronavirus 2019 (COVID-19) di Malaysia - From the Desk of the Director-General of Health Malaysia. https://kpkesihatan.com/2020/04/09/kenyataan-akhbar-kpk-9-april2020-situasi-semasa-jangkitan-penyakit-coronavirus-2019-covid-19-di-malaysia/

Abdullah, S. (2020d). Covid 19: Aduan talian internet lembap meningkat. Berita Harian online. http// www.bharian.com.my/node/670433/amp. 
Ahmad, N. (2020). Covid 19: guru, pelajar, ibu bapa sokong tangguh SPM. Berita Harian online. http;//www.bharian.com.my/node/.679709/amp.

Ali, N. N. N., \& Nasir, M. K. N. (2019). Keberkesanan pembelajaran atas talian dalam kalangan pelajar sekolah rendah [Paper presentation]. Prosiding Seminar Kebangsaan Pendidikan Negara (SKEPEN) ke-6, Bangi, Malaysia (pp. 657-666). Fakulti Pendidikan, UKM

Bavel, J. J. V., Baicker, K., Boggio, P. S., Capraro, V., Cichocka, A., Cikara, M., Crockett, M. J., Crum, A. J., Douglas, K. M., Druckman, J. N., Drury, J., Dube, O., Ellemers, N., Finkel, E. J., Fowler, J. H., Gelfand, M., Han, S., Alexander Haslam, S., Jetten, J., ... Willer, R. (2020). Using social and behavioural science to support COVID-19 pandemic response. Nature Human Behaviour, 4, 460-471. https://doi.org/10.1038/s41562-020-0884-z

Bergman, D., Bethell, C., Gombojav, N., Hassink, S., \& Stange, K. C. (2020). Physical Distancing With Social Connectedness. Annals of Family Medicine, 18(3), 272-277. https://doi.org/10.1370/afm.2538

Cahyani, R. (2020). Pengaruh penerapan disiplin belajar oleh orangtua terhadap hasil belajar siswa di SMP Negeri 24 Kota Jambi. https://repository.unja.ac.id/10726/

Carvalho, A. O. D., Ribeiro, I., Cirani, C. B. S., and Cintra, R. F. (2016). Organizational resilience: A comparative study between innovative and non-innovative companies based on the financial performance analysis. International Journal of Innovation 4: 58Duchek, S. (2020). Organizational resilience: a capability-based conceptualization. Business Research, 13, 215-246.

Jidin, M. R. M. (2020). Covid 19: UPSR PT3 tahun 2020 dibatalkan. Retrieved April 15 2020. From https:// www.google.com/berita-malaysia

Kamarudin, M. H., Yunus, N. K. Y., \& Razali, T. R. A. T. (2020). Pengaruh penerimaan teknologi dan budaya organisasi terhadap aplikasi 1Bestarinet. Jurnal Dedikasi, 14, 181-218. http://myjms.moe.gov.my/index.php/jd/article/view/7984/3370

Khalid, N. M., \& Quick, D. (2016). Teaching Presence Influencing Online Students' Course Satisfaction at an Institution of Higher Education. International Education Studies, 9, 62. https://doi.org/10.5539/ies.v9n3p62

Lan, T. P., Thuong, V. N., Quang, C. L., Thinh, V. N., \& Hieu, T. N. (2019). Importation and Humanto-Human Transmission of a Novel Coronavirus in Vietnam. The New England Journal of Medicine, 382(9). https://doi.org/10.1056/NEJMc2001272

Leow, S., Yee, W., Lee, C., \& Ean, C. (2020). Malaysian Private University Students ' Perception of Online Discussion Forums : A Qualitative Enquiry. Sains Humanika, 12(2), 31-38.

Malaysian Ministry of Education. (2020a). Garis panduan pelaksanaan pengajaran dan pembelajaran $(P d P)$ semasa perintah kawalan pergerakan disebabkan penularan jangkitan Covid-19. Surat Siaran Kementerian Pendidikan Malaysia Bilangan 3 Tahun 2020. moz-extension://1fa52177-cf87-4e1e-b329-c782d6cc980e/enhancedreader.html?openApp\&pdf=https\%3A\%2F\%2Fwww.moe.gov.my\%2Fpekeliling\%2F3361surat-siaran-kpm-bilangan-3-tahun-2020-garis-panduan-pelaksanaan-pengajaran-danpembelajaran-pdp-semasa-pkp-disebabkan-p

Malaysian Ministry of Education. (2020b). Standard operating procedure (SOP) pencegahan penularan jangkitan penyakit coronavirus 2019 (COVID-19) di sekolah KPM (13 Mac 2020). 
INTERNATIONAL JOURNAL OF ACADEMIC RESEARCH IN PROGRESSIVE EDUCATION AND

DEVELOPMENT

Vol. 9, No. 2, 2020, E-ISSN: $2226-6348$ @ 2020 HRMARS

https://www.moe.gov.my/en/muat-turun/pekeliling-dan-garis-panduan/3340-soppencegahan-penularan-jangkitan-penyakit-covid19-di-sekolah/file

Malaysian Communications and Multimedia Commission (2020). Kenyataan media. https://www.kkmm.gov.my/index.php/233-kpkk-news/16658-bernama-28-march-2020enough-bandwidth-capacity-to-go-around-but

Nasir, M. K. M., Surat, S., Maat, S. M., Abd Karim, A., \& Daud, M. Y. (2018a). Confirmatory Factor Analysis on the Sub-Construct of Teaching Presence's in the Community of Inquiry. Creative Education. 9, 2245-2253. https://doi.org/10.4236/ce.2018.914165

Nasir, M. K. N., Mansor, A. Z., and Rahman, M. J. A. (2018b). Measuring Malaysian online university student social presence in online course offered. Journal of Advanced Research in Dynamical and Control Systems. 10(12), 1442 - 1446.

Malaysian Ministry of Health. (2020). Situasi semasa pandemik COVID-19 di Malaysia. http://covid-19.moh.gov.my/archive:may_2020

Mat, N. F. C., Edinur, H. A., Razab, M. K. A. A., \& Safuan, S. (2020). A single mass gathering resulted in massive transmission of COVID-19 infections in Malaysia with further international spread. Journal of Travel Medicine, 2020, 1-4. https://doi.org/10.1093/jtm/taaa059

Min, H., \& Nasir, M. K. M. (2020). Self-Regulated Learning in A Massive Open Online Course: A Review of Literature. European Journal of Interactive Multimedia and Education, 1(2), https://doi.org/10.30935/ejimed/8403

National Security Council. (2020). Covid 19-Internet Percuma 1 Gb. 1 April 2020. Retrieved 15 May 2020, From https:// www.mkn.gov.my/web/ms/202004/01/ covid-19-internetpercuma $-1 \mathrm{gb} /$.

Rampal, L., \& Liew, B. S. (2020). Coronavirus disease (COVID-19) pandemic. Med J Malaysia, 75(2), 95-97. https://doi.org/10.1056/NEJMoa2002032

Ruzki, R. M., Muzammir, M. Y., \& Sulaiman, N. A. (2020). COVID-19: 58 pesakit sembuh hari ini. Berita Harian Online.

https://origin.bharian.com.my/berita/nasional/2020/05/688428/covid-19-58-pesakitsembuh-hari-ini

Rizzato, F., Fenwick, S., \& Fogg, I. (2020). Mobile experience during the Covid 19 pandemic: 4g download speed. Retrieved 14 April 2020. From https:// www.opensignal.com/.2020/04/08

Rotondi, V., Andriano, L., Dowd, J. B., \& Mills, M. C. (2020). Early evidence that social distancing and public health interventions flatten the COVID-19 curve in Italy. https://osf.io/wah4e

Rovai, A. P., \& Downey, J. R. (2010). Why Some Distance Education Programs Fail while Others Succeed in a Global Environment. The Internet and Higher Education, 13, 141-147. https://doi.org/10.1016/j.iheduc.2009.07.001

Sawalha, I. H. S. (2015). Managing adversity: understanding some dimensions of organizational resilience. Management Research Review, 38, 346-366.

Simpson, O. (2018). Supporting Students in Online, Open and Distance Learning (2nd ed.). Routledge.

Suhaimi, F. (2020). Fahami perbezaan epidemik, endemik dan pandemik. Astro Awani. http://www.astroawani.com/berita-malaysia/fahami-perbezaan-epidemik-endemikdan-pandemik-233401 
Tahir, A. N., \& Noorzali, I. (2020). Sedia hadapi kelas maya sesuai normal baharu. Berita Harian Online. https://www.bharian.com.my/berita/nasional/2020/04/679003/sedia-hadapikelas-maya-sesuai-normal-baharu

UNESCO. (2020). Distance learning strategies in response to COVID-19 school closures - UNESCO Digital Library. UNESCO.

https://unesdoc.unesco.org/ark:/48223/pf0000373305?posInSet=2\&;queryld=N-

8ea77989-29de-4ff3-997c-eaddc678be5b

Wisneski, J. E., Ozogul, G., \& Bichelmeyer, B. A. (2017). Investigating the impact of learning environments on undergraduate students' academic performance in a prerequisite and post-requisite course sequence. The Internet and Higher Education, 32, 1-10. https://doi.org/https://doi.org/10.1016/j.iheduc.2016.08.003

World Health Organization [WHO]. (2020a). Novel coronavirus (2019-nCov): Situation report - 1, 21 January 2020.

World Health Organization [WHO]. (2020b). Coronavirus: Overview, prevention and symptoms. World Health Organization. https://www.who.int/health-topics/coronavirus\#tab=tab_3 